\title{
First report of Trichodorus primitivus, $T$. sparsus and T. viruliferus (Nematoda: Trichodoridae) from the Czech Republic
}

\author{
S. KUMARI ${ }^{1}$, W. DECRAEMER ${ }^{2,3}$ \\ ${ }^{1}$ Crop Research Institute, Division of Plant Health, Drnovská 507, Ruzyně, 16106 Prague 6, Czech Republic, \\ E-mail: kumari@vurv.cz; ${ }^{2}$ Royal Belgian Institute of Natural Sciences, Department of Invertebrates, Vautierstraat 29, \\ 1000 Brussels, Belgium; ${ }^{3}$ Department of Biology, Ghent University, Ledeganckstraat 35, 9000 Ghent, Belgium
}

\begin{abstract}
Summary
A survey has been carried out to study the occurrence and distribution of Trichodorus primitivus, T. sparsus and $T$. viruliferus in the Czech Republic under the rhizosphere of orchards, forests, vineyards and strawberry. Total 208 sites were surveyed and only 29 sites were found positive for these species. All three species are reported in the Czech Republic for the first time.
\end{abstract}

Keywords: Trichodorus primitivus; Trichodorus sparsus; Trichodorus viruliferus; Czech Republic; nematode

\section{Introduction}

Nematodes belonging to the genus Trichodorus are polyphagous migratory ectoparasites (Decraemer, 1995). Direct feeding of trichodorid nematodes on the root system causes stunting of the roots, a symptom reflected in the vernacular name of the group as "stubby root nematodes". In addition, 4 species (T. cylindricus, T. primitivus, T. similis and T. viruliferous) out of 56 species are known to vector tobraviruses which cause economically important diseases to potatoes and other crops (Taylor \& Brown, 1997; Mumford et al., 2000).

In the Czech Republic, first record of $T$. similis and $T$. variopapillatus was reported by Kumari et al., (2007) and Kumari and Decraemer (2009), but no overview study on the occurrence of Trichodorus species from the Czech Republic is available. This study deals with the geographical distribution of Trichodorus primitivus, T. sparsus and T. viruliferus in the Czech Republic and provides some additional information on morphological characters. The three species identified during the survey each represent first records for Czech nematofauna.

\section{Materials and methods}

The occurrence of trichodorid associated with orchards, vineyards, forest and strawberry was examined in a survey carried out in the Czech Republic from 2003 to 2009; a total of 208 sites were surveyed. Specimens for morphometric and morphological analysis from the field samples were extracted by sieving over $1 \mathrm{~mm}, 150 \mu \mathrm{m}$ and $75 \mu \mathrm{m}$ and placing the residual on a tissue paper on a Baermann funnel from $24-48$ hours (Brown \& Boag, 1988). Nematodes were heat killed, fixed in TAF, processed in slow glycerin process and mounted in anhydrous glycerin on slides. Photomicrographs were recorded with a digital camera linked to a computer and measurements were made with the aid of imaging software (Olympus DPsoft).

\section{Results}

Total 208 sites were surveyed and only 29 sites were found positive for the presence of Trichodorus primitivus, $T$. sparsus or T. viruliferus. Out of which 108 were from orchards (positive 7), 62 forests (positive 18), 35 vineyards (positive 3 ) and 2 strawberries (positive 1). More sites $(62 \%)$ were found positive under the rhirzosphere of forest trees compare to other fauna studied.

$\underline{\text { Trichodorus primitivus (de Man, 1880) Micoletzky, } 1922}$ syn. Dorylaimus primitivus de Man, 1880.

syn. Trichodorus castellanensis Arias Delgado, Jimenez Millan and Lopez Pedregal, 1965

syn. Trichodorus mirabilis Ivanova, 1977

Morphometrics of males and females are presented in Table 1 and Table 2. Male habitus J-shaped. Males with three ventromedian cervical papillae (CP) anterior to excretory pore. Anterior papilla about mid-onchiostyle region, the middle papilla at base of onchiostyle and third CP opposite the nerve ring. Digestive system typical of genus; pharynx offset from intestine. Spicules slightly curved. 
Table 1. Morphometrics of male of Trichodorus primitivus (de Man, 1880) Micoletzky, 1922, Trichodorus sparsus Szcygiel, 1968 and Trichodorus viruliferus Hooper, 1963.

Measurements in $\mu \mathrm{m}$ (in form): mean \pm standard deviation (range).

\begin{tabular}{|c|c|c|c|}
\hline $\begin{array}{l}\text { Species } \\
\text { Locality } \\
\text { Host } \\
\end{array}$ & $\begin{array}{c}\text { T. primitivus } \\
\text { Ratiškovice } \\
\text { peach }\end{array}$ & $\begin{array}{c}\text { T. sparsus } \\
\text { Kámen } \\
\text { forest } \\
\end{array}$ & $\begin{array}{c}\text { T. viruliferus } \\
\text { Bílé podolí } \\
\text { plum }\end{array}$ \\
\hline $\mathrm{n}$ & 3 & 8 & 5 \\
\hline $\mathrm{L}$ & $\begin{array}{c}679 \pm 110 \\
(555-767)\end{array}$ & $\begin{array}{c}990 \pm 60 \\
(878-1075)\end{array}$ & $\begin{array}{l}754 \pm 67.5 \\
(648-815)\end{array}$ \\
\hline Body width & $\begin{array}{l}33 \pm 2.08 \\
(31-35)\end{array}$ & $\begin{array}{l}43 \pm 3.77 \\
(38-48)\end{array}$ & $\begin{array}{l}38 \pm 2.28 \\
(34-40)\end{array}$ \\
\hline Neck length & $\begin{array}{l}162 \pm 3.05 \\
(159-165)\end{array}$ & $\begin{array}{l}163 \pm 18.77 \\
(134-196)\end{array}$ & $\begin{array}{l}140 \pm 6.88 \\
(132-150)\end{array}$ \\
\hline Onchiostyle & $\begin{array}{l}42 \pm 3.05 \\
(39-45)\end{array}$ & $\begin{array}{l}63 \pm 4.79 \\
(56-71)\end{array}$ & $\begin{array}{l}38 \pm 1.58 \\
(36-40)\end{array}$ \\
\hline Anterior to $\mathrm{CP} 1$ & $\begin{array}{l}27 \pm 4.61 \\
(24-31)\end{array}$ & $\begin{array}{l}97 \pm 4.16 \\
(92-105)\end{array}$ & $\begin{array}{c}35 ; 39 * \\
-\end{array}$ \\
\hline $\mathrm{CP} 1$ to $\mathrm{CP} 2$ & $\begin{array}{l}28 \pm 3.61 \\
(24-31)\end{array}$ & $\begin{array}{l}18 \pm 3.15 \\
(14-23)\end{array}$ & $\begin{array}{c}21 ; 25^{*} \\
-\end{array}$ \\
\hline $\mathrm{CP} 2$ to $\mathrm{CP} 3 / \mathrm{EP}$ & $\begin{array}{l}24 \pm 5.13 \\
(18-28)\end{array}$ & $\begin{array}{l}8 \pm 3.31 \\
(5-13)\end{array}$ & $\begin{array}{c}18 ; 22 * \\
-\end{array}$ \\
\hline $\mathrm{CP} 3$ to $\mathrm{EP}$ & $\begin{array}{l}10 \pm 1.00 \\
(9-11)\end{array}$ & $\begin{array}{l}- \\
-\end{array}$ & $\begin{array}{c}22 ; 24^{*} \\
-\end{array}$ \\
\hline Spicules & $\begin{array}{l}40 \pm 0.58 \\
(39-40)\end{array}$ & $\begin{array}{l}52 \pm 2.45 \\
(47-54)\end{array}$ & $\begin{array}{l}26 \pm 2.07 \\
(23-28)\end{array}$ \\
\hline Cloaca to SP1 & $\begin{array}{l}24 \pm 1.53 \\
(23-26)\end{array}$ & $\begin{array}{l}38 \pm 3.64 \\
(31-43)\end{array}$ & $\begin{array}{l}30 \pm 2.49 \\
(28-34)\end{array}$ \\
\hline SP1 to SP2 & $\begin{array}{l}32 \pm 4.58 \\
(27-36)\end{array}$ & $\begin{array}{l}47 \pm 5.19 \\
(36-53)\end{array}$ & $\begin{array}{l}30 \pm 1.64 \\
(28-32)\end{array}$ \\
\hline $\mathrm{SP} 2$ to $\mathrm{SP} 3$ & $\begin{array}{l}38 \pm 6.81 \\
(30-43)\end{array}$ & $\begin{array}{l}57 \pm 2.26 \\
(51-62)\end{array}$ & $\begin{array}{c}40 \pm 7.77 * * \\
(31-46)\end{array}$ \\
\hline $\mathrm{a}$ & $\begin{array}{c}20.9 \pm 4.54 \\
(15.9-24.7)\end{array}$ & $\begin{array}{c}23 \pm 2.07 \\
(21.1-27.6)\end{array}$ & $\begin{array}{c}19.9 \pm 1.05 \\
(19.0-21,2)\end{array}$ \\
\hline $\mathrm{b}$ & $\begin{array}{l}4.2 \pm 0.71 \\
(3.4-4.8)\end{array}$ & $\begin{array}{l}6.1 \pm 0.80 \\
(4.9-7.3)\end{array}$ & $\begin{array}{l}5.4 \pm 0.66 \\
(4.6-6.2)\end{array}$ \\
\hline $\mathrm{T}$ & $\begin{array}{l}61 \pm 0.21 \\
(61-61)\end{array}$ & $\begin{array}{l}61 \pm 3.19 \\
(57-66)\end{array}$ & $\begin{array}{l}62 \pm 1.98 \\
(61-65)\end{array}$ \\
\hline
\end{tabular}

Shaft conical which is not offset from manubrium. Three ventromedian precloacal supplements present at the tail end. Female largely similar to male except for general appearance typical for the genus. Vaginal sclerotizations rodshaped. Vulva transverse slit and vagina rhomoboid. Vaginal sclerotized pieces $2.5-3.5 \mu \mathrm{m}$ apart. Orientations of vaginal sclerotized pieces parallel to vagina lumen. Phary- neal bulb usually offset.

T. primitivus was recorded at three sites (Borek, Přelovice and Ratiškovice) out of 208 studied sites.

\section{Trichodorus sparsus Szcvgiel, 1968}

Morphometrics of males and females are presented in Table 1 and Table 2. Photomicrographs are presented in Fig.1 showing entire nematodes (1A, 1B), male anterior and posterior region $(1 \mathrm{C}, 1 \mathrm{E})$ and female posterior region (1D). Male body habitus J-shaped. Males possess two ventromedian cervical papillae anterior to the excretory pore. Spicules paried, slightly ventrally curved. Wide manubrium not offset from shaft. Large sperm cells with large sauage-shaped nucleus. Terminal tail cuticle strongly thickened with the terminus often bulging out drop-like. Three ventromedian precloacal papillae present. The first one opposite the proximal end of the spicules, second 47 $\mu \mathrm{m}$ from the first one and third one at $57 \mu \mathrm{m}$ from the second one. Excretory pore opposite the isthmus.

Females with pore-like vulva in ventral view, the vaginal sclerotizations small triangular to rounded triangular. Vaginal sclerotized pieces slightly separated 1-2 $\mu \mathrm{m}$ apart. Orientation of vaginal sclerotized pieces oblique. Sperm located in spermatheca or concentrated near the oviduct. Vagina barrel-shaped. Genital system didelphic. Pharyngeal bulb offset.

Table 2. Morphometrics of females of Trichodorus primitivus (de Man, 1880) Micoletzky, 1922, Trichodorus sparsus Szcygiel, 1968 and Trichodorus viruliferus Hooper, 1963.

Measurements in $\mu \mathrm{m}$ (in form): mean \pm standard deviation (range).

\begin{tabular}{|c|c|c|c|}
\hline Species & $\begin{array}{c}T . \\
\text { primitivus }\end{array}$ & T. sparsus & $\begin{array}{c}T . \\
\text { viruliferus }\end{array}$ \\
\hline Locality & Raiškovice & Kámen & Bílé podolí \\
\hline Host & peach & forest & plum \\
\hline $\mathrm{n}$ & 5 & 8 & 3 \\
\hline $\mathrm{L}$ & $\begin{array}{c}686 \pm 63 \\
(610-761)\end{array}$ & $\begin{array}{c}953 \pm 68 \\
(848- \\
1054)\end{array}$ & $\begin{array}{l}785 \pm 37.87 \\
(754-827)\end{array}$ \\
\hline \multirow[t]{2}{*}{ Body width } & $33 \pm 1.14$ & $45 \pm 2.56$ & $43 \pm 6.66$ \\
\hline & $(32-35)$ & $(40-48)$ & $(36-49)$ \\
\hline \multirow[t]{2}{*}{ Neck length } & $146 \pm 7.43$ & $178 \pm 14.00$ & $143 \pm 6.11$ \\
\hline & $(136-156)$ & $(156-204)$ & $(138-150)$ \\
\hline \multirow[t]{2}{*}{ Onchiostyle } & $48 \pm 7.23$ & $63 \pm 2.67$ & $43 \pm 1.00$ \\
\hline & $(36-54)$ & $(59-67)$ & $(42-44)$ \\
\hline \multirow[t]{2}{*}{$\begin{array}{l}\text { Length of } \\
\text { vagina }\end{array}$} & $20 \pm 1.00$ & - & $8 ; 12 * *$ \\
\hline & $(19-21)$ & - & - \\
\hline $\mathrm{a}$ & $\begin{array}{c}20.6 \pm 2.09 \\
(18.5- \\
23.8)\end{array}$ & $\begin{array}{c}21.4 \pm 2.12 \\
(19.2- \\
25.2)\end{array}$ & $\begin{array}{c}18.4 \pm 2.55 \\
(15.8- \\
20.9)\end{array}$ \\
\hline \multirow[t]{2}{*}{$\mathrm{b}$} & $4.7 \pm 0.45$ & $5.4 \pm 0.70$ & $5.5 \pm 0.43$ \\
\hline & $(4.1-5.3)$ & $(4.2-6.2)$ & $(5.2-6.0)$ \\
\hline \multirow[t]{2}{*}{ V } & $57 \pm 1.58$ & $56 \pm 1.70$ & $55 \pm 0.80$ \\
\hline & $(55-59)$ & $(54-58)$ & $(54-56)$ \\
\hline
\end{tabular}




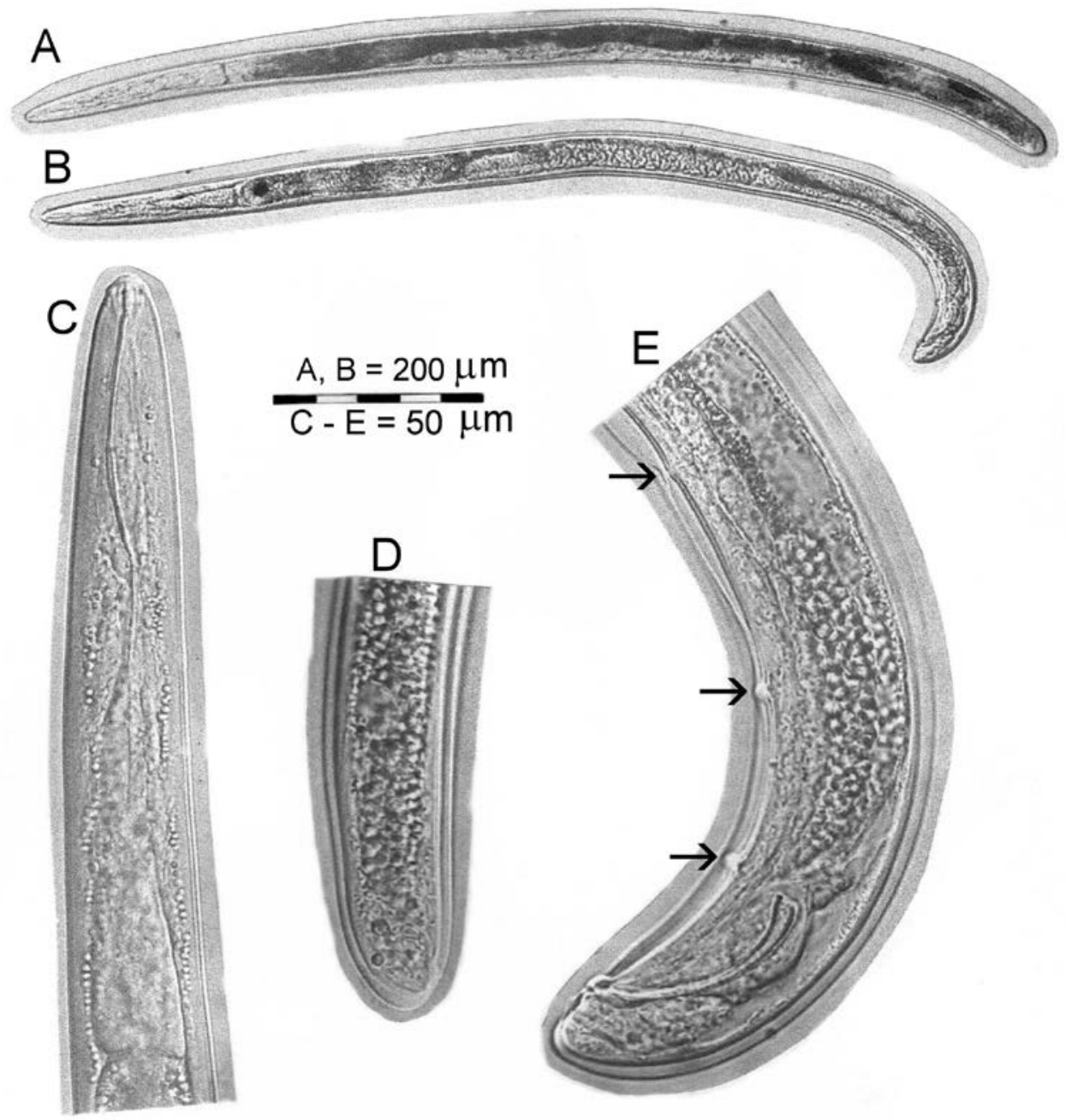

Fig. 1: Trichodorus sparsus Szcygiel, 1968. A: Entire female; B: Entire male; C: male anterior region; D: female posterior region; $\mathrm{E}$ : male posterior region (arrow indicating supplements)

It was found at 15 sites (Brodce, Choumky, Hlínoviště, Janov, Jetříchovice, Kámen, Kozí hory, Lysá nad Labem, Mcely, Mezní louka, Obrubce, Ohaveč, Přelovice, Staré splavy and Vojitěchov) out of 208 sites.

\section{Trichodorus viruliferus Hooper, 1963}

Morphometrics of males and females are presented in Table 1 and Table 2. Photomicrographs of male are presented in Fig. 2 showing entire nematode (2A) and anterior and posterior region $(2 \mathrm{~B}, 2 \mathrm{C}, 2 \mathrm{D})$. Male habitus J-shaped when heat killed. Males with three ventromedian cervical papillae anterior to excretory pore. Anterior to the excretory pore three cervical papillae present. First at onchiostyle region; second just posterior to the onchiostyle base. Spicules paired and ventrally curved. In the middle of the spicules there is a distinct and characteristic narrow bend with a few bristles. Three ventromedian precloacal supplements present and equally spaced. Posterior supplement lies just anterior to retracted spicules. Large sperm cells sausage-shaped with large nucleus. Excretory pore along the anterior two-thirds of the pharyngeal bulb.
Female genital system didelphic. Vulva pore like. Vaginal sclerotizations oval-shaped, oblique or almost parallel to vaginal lumen and widely separated from each other. Vagina more or less rhomboid-shaped. Sperm located in spermatheca or concentrated near the oviduct. Pharynx offset or with small overlapping of ventrosublateral pharyngeal glands. Males and females found in about equal numbers.

T. viruliferus was recorded from three sites Bílé Podolí, Ratiškovice and Vysoká.

\section{Discussion}

Morphometrics of females and males of $T$. primitivus are within the ranges described by Decraemer (1995). Morphometrics of females and males of $T$. sparsus are in close agreement with original description of the species except onchiostyle length (Szcygiel, 1968). Onchiostyle length of the Czech population is much larger (female and male 63 vs $48 \mu \mathrm{m}$ ), but within the minimum-maximum ranges described by Decraemer (1995). Morphometrics of females 


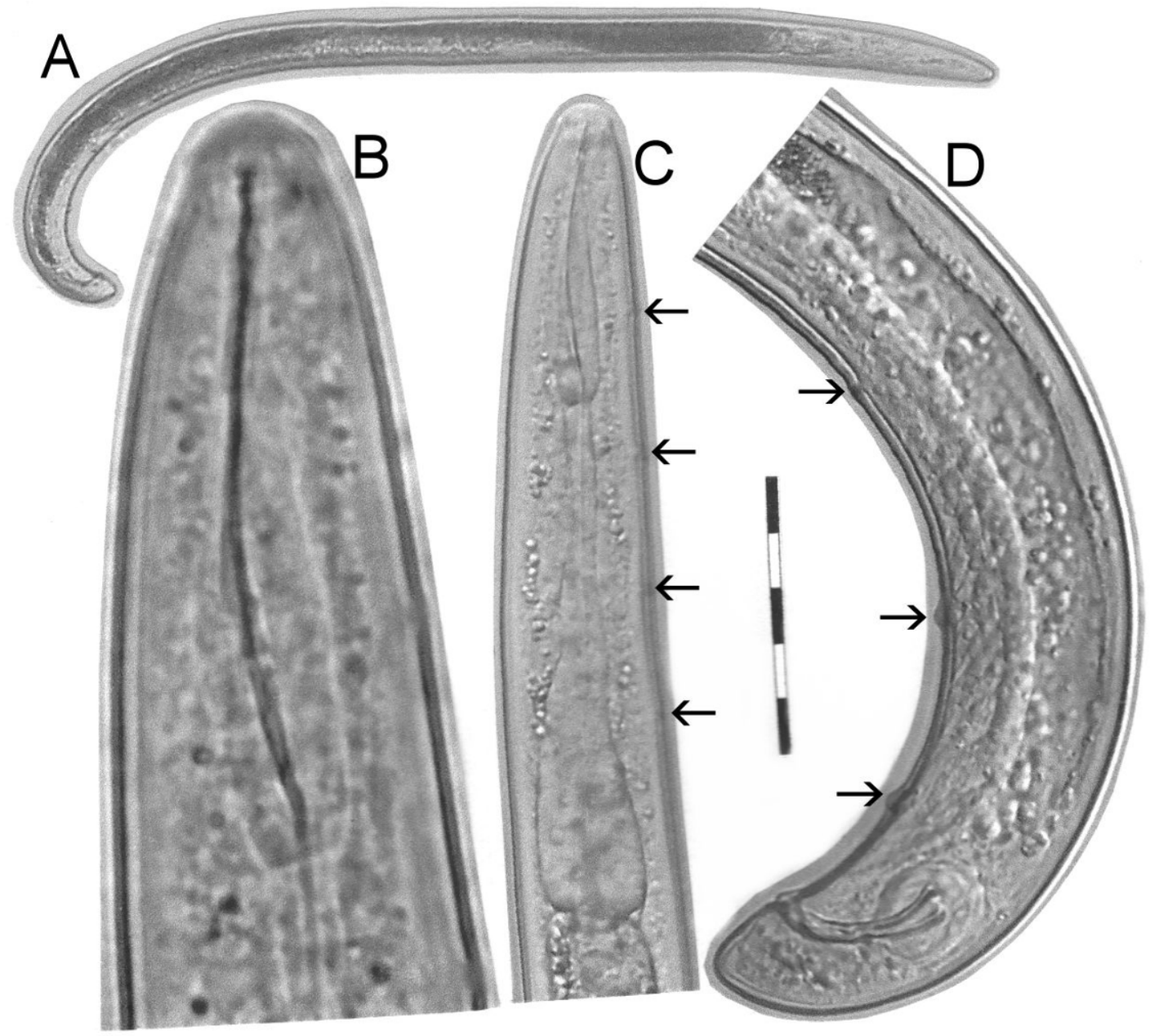

Fig. 2. Trichodorus viruliferus Hooper, 1963. Male, A: Entire nematode; B, C: Anterior region (arrow indicating cervical papillae); D: Tail (arrow indicating supplements). Scale bar, A: $200 \mu \mathrm{m}$; B: $20 \mu \mathrm{m}$; C-D: $50 \mu \mathrm{m}$.

of $T$. viruliferus are also in close agreements with the original description of the species (Hooper, 1963) except smaller ratio 'a' (18.4 vs 24). Morphometrics of males of T. viruliferus also compared with the original description of the species showed some variations. Onchiostyle length (38 vs $45 \mu \mathrm{m})$ spicules length $(25.6$ vs $34 \mu \mathrm{m})$ and ratio 'a' (19.9 vs 26) are shorter, but within the ranges described by Decraemer (1995).

Of the three trichodorid species reported here $T$. primitivus and $T$. viruliferus are proved to be vectors of tobraviruses (Taylor \& Brown, 1997). However, to determine if populations of these species occurring in the Czech Republic can transmit Tobraviruses requires further study.

Systematic research on Trichodorus is time consuming and novel techniques that will facilitate detection of Trichodorus in a sensitive and specific way are increasingly being sought. New methodologies employing polymerase chain reaction and DNA sequencing has been reported (Boutsika et al., 2004a; Boutsika et al., 2004b). In these studies PCR with a species-specific differentiation constitutes a major step forward in developing DNA diagnostics. Therefore, molecular characterization will be the subject of our further study.

\section{Acknowledgements}

The work was supported by the Ministry of Agriculture of the Czech Republic, Project number MZe - 0002700604, etapa 09.

\section{References}

Boutsika, K., Brown, D. J. F., Philips, M. S., Blok, V. C. (2004a): Molecular characterisation of the ribosomal DNA of Paratrichodorus macrostylus, P. pachydermus, Trichodorus primitivus and T. similis (Nematoda: Trichodoridae). Nematology, 6: 641 - 654. DOI: 10.1163/1568541042843432

Boutsika, K., Phillips, M. S., MacFarlane, S. A., Brown, D. J. F., Holeva, R. C., BloK, V. C. (2004b): Molecular diagnostics of some trichodorid nematodes and associated Tobacco rattle virus. Plant Pathology, 53: $110-$ 116. DOI: 10.1046/j.1365-3059.2003.00938.x

Brown, D. J. F., BoAG, B. (1988): An examination of methods used to extract virus-vector nematodes (Nematoda: Longidoridae and Trichodoridae) from soil samples. Nematol. Medit., 16: 93 - 99 
DECRAEMER, W. (1995): The family Trichodoridae: Stubby root and virus vector nematodes. Kluwer Academic Publishers, The Netherlands.

HoOper, D. J. (1963): Trichodorus viruliferus n. sp. (Nematoda: Dorylaimida). Nematologica, 9: 200 - 204

Kumari, S., Decraemer, W. (2009): First report of Trichodorus variopapillatus (Nematoda: Trichodoridae) from the Czech Republic. Plant Dis., 93: 966. DOI: 10.1094/PDIS-93-9-0966A

Kumari, S., Vohanka, J., Decreamer, W. (2007): First report of Trichodorus similis from the Czech Republic (Nematoda: Trichodoridae). Plant Dis., 91: 228. DOI:

RECEIVED APRIL 20, 2010
10.1094/PDIS-91-2-0228B

Mumford, R. A., Walsh, K., Barker, I., BoOnham, N. (2000): Detection of Potato mop top virus and Tobacco rattle virus using a multiplex real-time fluorescent reversetranscription polymerace chain reaction assay. Phytopathology, 90: $448 \quad-\quad 453 . \quad$ DOI: 10.1094/PHYTO.2000.90.5.448

SzCYGIEL, A. (1968): Trichodorus sparsus sp. n. (Nematoda, Trichodoridae). Bulletin de L'académie Polonaise des Science 16: 695 - 698

TAYLOR, C. E., BROWN, D. J. F. (1997): Nematode vectors of plant viruses. CABI, UK.

ACCEPTED MAY 26, 2011 